\title{
Characterization of flow units, rock and pore types for Mishrif Reservoir in West Qurna oilfield, Southern Iraq by using lithofacies data
}

\author{
Ahmed N. Al-Dujaili ${ }^{1} \cdot$ Mehdi Shabani ${ }^{1} \cdot$ Mohammed S. AL-Jawad $^{2}$
}

Received: 11 August 2021 / Accepted: 9 September 2021 / Published online: 17 September 2021

(c) The Author(s) 2021

\begin{abstract}
This study has been accomplished by testing three different models to determine rocks type, pore throat radius, and flow units for Mishrif Formation in West Qurna oilfield in Southern Iraq based on Mishrif full diameter cores from 20 wells. The three models that were used in this study were Lucia rocks type classification, Winland plot was utilized to determine the pore throat radius depending on the mercury injection test (r35), and (FZI) concepts to identify flow units which enabled us to recognize the differences between Mishrif units in these three categories. The study of pore characteristics is very significant in reservoir evaluation. It controls the storage mechanism and reservoir fluid properties of the permeable units while pore structure is a critical controlling factor for the petrophysical properties and multiphase-flow characteristics in reservoir rocks. Flow zone indicator (FZI) has been used to identify the hydraulic flow units approach (HFUs). Each (HFU) was reproduced by certain FZI and was supposed to have similar geological and petrophysical properties. The samples were from four lithofacies, $\mathrm{mA}, \mathrm{CRII}, \mathrm{mB} 1$, and $\mathrm{mB} 2$. Because of the wide range of cored-wells samples (20 wells), this paper is updated the previous studies and indicated some differences in the resulting categories. It was noticed as results of this study that the rocks types of the lower Mishrif were mostly ranged from wackestone to packstone in the upper part of mB2 which reflected mid-ramp facies while the upper part of $\mathrm{mB} 2$ referred to shoal facies and for the $\mathrm{mB} 1$ unit the rocks types mostly range from packstone to grainstone with some points as wackestone marked as shoal and rudist bioherm facies. Grainstone relatively decreases with the increasing of depth from upper to lower Mishrif while wackestone and packstone indicated increasing in the same direction. The unit $\mathrm{mA}$ is marked as mesopores and macropores, while megapores and macropores feature increased in $\mathrm{mB} 1$ which has been noticed in the northern part of West Qurna oilfield due to increasing shoal and rudist bioherm facies, the $\mathrm{mB} 2$ unit revealed increasing in mesoporous and decreasing in megaporous. The upper Mishrif $(\mathrm{mA})$ has three flow units, while the lower Mishrif $(\mathrm{mB} 1, \mathrm{mB} 2)$ has eight flow units four for each reservoir unit.
\end{abstract}

Keywords West Qurna $\cdot$ Mishrif formation · Rocks type · Pore throat radius · Flow units

\section{Introduction}

It's known that carbonate rocks cover about $30 \%$ of the sedimentary rocks and comprise $60 \%$ of the convention hydrocarbon in global reservoirs (Ahr 2008). Heterogeneity and complication are the challenges to comprehend the

Ahmed N. Al-Dujaili

ahmed.noori203@aut.ac.ir

1 Petroleum Engineering Department, AmirKabir University of Technology, Tehran, Iran

2 Petroleum Engineering Department, University of Baghdad, Baghdad, Iraq depositional model and facies distribution. Core tests are the first tool to study petrophysical properties but it's not likely to get plugs from each well to understand rocks' properties and stratigraphic accumulating patterns.

Rock type and pore throat radius dominate the relationship between porosity and permeability. Porosity and permeability can be determined directly as in this study from core analysis. The pore characteristics are one of the quite considerable properties in reservoir evaluation. It dominances the storage mechanism and reservoir fluid properties of the permeable units while pore structure is a critical prevailing factor for the petrophysical properties and multiphase-flow characteristics in reservoir rocks. Flow zone indicator (FZI) has been used to identify the hydraulic flow units approach 
(HFUs). Each (HFU) is reproduced by certain FZI and is supposed to have similar geological and petrophysical properties. Core data from 20 wells were used to determine the rocks type, the pore throat radius, and flow units for each reservoir unit. Core data from 20 wells were used to determine the rocks type, the pore throat radius, and flow units for each unit of Mishrif Formation in West Qurna oilfield in Southern Iraq. The discrete facies sequence is produced either from core measurements (lithofacies) or clustered from the well logging data (electrofacies) (Tang et al. 2004).

Recently partitioning algorithms Partitioning Around Mediods (PAM) and $K$-means cluster analysis have been used to analyze well log data in R-statistical computing language (McCreery and Al-Mudhafar 2017).

\section{Literature review}

\section{Rocks type}

The pore system can be classified according to the structure of the selective deposits (Choquette 1970). Geologists, analyzers, and reservoir managers used the Archie and Lucia tabulations. Lucia's procedure disparities the sedimentologic and diagenesis practicability with physical properties depending on Archie's compilation (Liu 2018), which has three main pore type classes, and the distribution and interconnection of pores are different for each kinds (Lucia 2007).

Rocks type was classified into types that have the same deposition conditions and identical diagenesis practicability (Lucia 2007). Pore size, porosity, sorting, and separate vugs porosity are the main factors affecting rocks types. This classification has three categories of rocks type (Lucia 2007) Table 1:

Lucia (2007) gives a comprehensive formula known as rocks fabric number (RFN) Fig. 1.

$\log k=\{9.7982-12.0803 \log (\mathrm{RFN})$

$$
+[8.6711-8.2965 \log (\mathrm{RFN})] \log \varphi\}
$$

Many papers have been published focused on rocks type for Mishrif Formation in West Qurna oilfield (Liu et al.

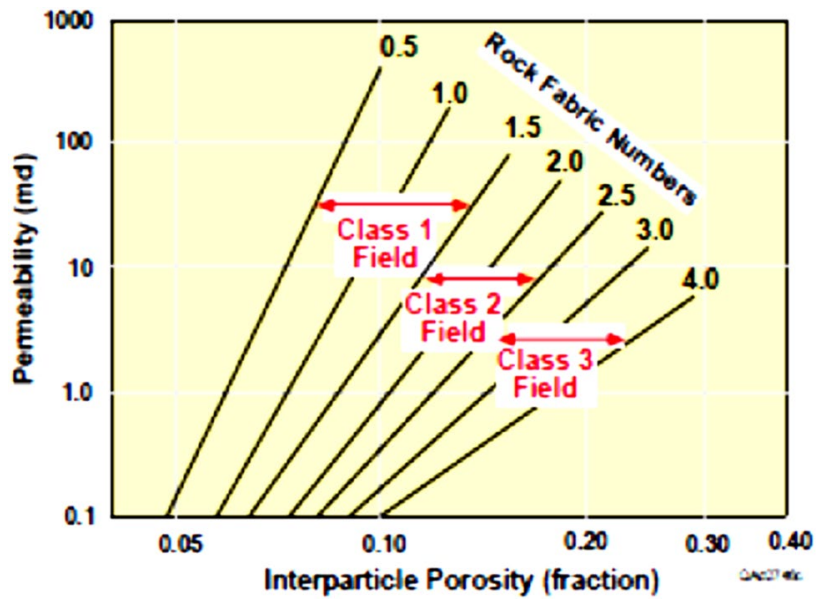

Fig. 1 Lucia rocks type

2018), (Ismail and Al-Najm 2019), (Deng Ya et al. 2016), and (Hussain et al. 2020).

Clustering analysis has been used by Abbas et al. (2019) as an unsupervised machine learning technique to collect a set of data into clusters with no predefined classes for three wells in the upper shale member/Zubair formation in Luhais oil field southern Iraq. In the research of (Al-Mudhafar et al. 2019), data from heterogeneous carbonate reservoir and two different clustering algorithms, $K$-mean approach and Calinski-Harabasz solution were used to classify reservoir facies based on the given data.

\section{Pore throat radius}

A new empirical relationship between porosity, air permeability had been developed. Winland, who was concerned about the pores interconnecting consistently with a saturation of mercury in 35\% which is written as to form (r35) for a group of sandstones and carbonates samples (Winland 1976). Winland computed the regressions for percentiles (e.g., 30, 40, and 50), but the best regression (highest $R$ ) was obtained at $35 \%$. Why $35 \%$ resulted in the best correlation, no explanation was given.

Winland's R35 Equation is as follows:

Table 1 Rocks type according to (Lucia, 2007)

\begin{tabular}{llll}
\hline Class \# & Grain size $\mu \mathrm{m}$ & Rocks type & Affecting factors \\
\hline Class 1 & More than 100 & Almost grainstone & Grain size, sorting, and inter-grain cement content \\
Class 2 & Between 20 and 100 & Predominated by packstone & Grain size, inter-grain micrite, and cement \\
Class 3 & Less than 20 & $\begin{array}{l}\text { Pack-wackestone, wackestone, and } \\
\text { mudstone }\end{array}$ & Inter-particle porosity and micrite particle size \\
\hline
\end{tabular}


Table 2 Pore throat type

\begin{tabular}{ll}
\hline Pore throat type & Radius microns \\
\hline Megapores & More than 10 \\
Macropores & Between 2.5 and 10 \\
Mesopores & Between 0.5 and \\
& 2.5 \\
Micropores & Between 0.2 and \\
& 0.5 \\
Nanopores & Smaller than 0.2 \\
\hline
\end{tabular}

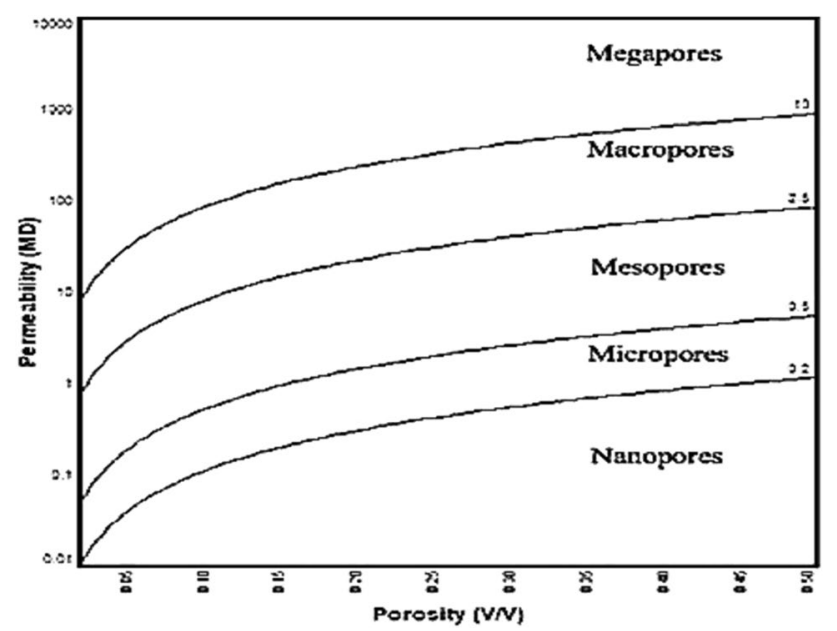

Fig. 2 Pore throat radius classification

$\log 35=\left\{0.732+0.588 \log \left(k_{\text {air }}\right)-0.864 \log \varphi\right\}$

Pore throat radius can be recognized as (Porras and Campos 2001) Table 2, Fig. 2.

(Awadeesian et al. 2015) studied the facies classification, and associated most important diagenetic impacts on pore development for Mishrif Formation in West Qurna oilfield. (Ismail and Al-Najm 2019) was concerned with the relevance between petrophysical properties (porosity and permeability), using lithofacies and NMR data, and then corresponding the results to define rocks type and pore throat radius.

It can conclude that the Winland R35 method is the best method of rock typing in predicting the core permeability values (Haikel et al. 2018).

\section{Flow units}

Flow unit is defined as a part of the reservoir, where the petrophysical and geological properties that impact fluid flow are regular and proportionally foretell by the features of other rock sizes (Ebanks 1992), While it is defined as stratigraphically continuous segregation of a similar reservoir process that regards the geological framework and preserves the rock type characteristics (Gunter 1997). In simplification terms, the porosity, permeability, and bed thickness data are using to determine the flow unit. Cores flow units specified in the sedimentary environment, structure, capillary curves, and petrophysical properties (Abbaszadeh 1996).

The concept of flow unit contributes to:

- Quantitative definition and mapping of the parts of the reservoir in terms of reservoir behavior.

- Realistic building block for reservoir zonation, which was advantageous to numerical simulation of the reservoir performance (Hearn et al. 1984).

Various methods have been developed for flow unit identification, based on descriptions of pore geometry, a depositional environment of rock structure, and diagenetic process. These methods include relationships between reservoir quality and rock type.

The Reservoir quality index (RQI) and Flow zone indicator (FZI) concepts have been identified to derive flow units. The RQI and FZI are defined as in the Eqs. (3-5) (Amaefule et al. 1993).

$\mathrm{RQI}(\mu \mathrm{m})=0.0324\left(\sqrt{K / \varphi_{e}}\right)$

$\mathrm{FZI}=\operatorname{RQI}\left(\varphi_{\mathrm{z}}\right)$

The $\left(\varphi_{\mathrm{z}}\right)$ is the ratio of pore volume to grain volume and defined mathematically as:

$\varphi_{\mathrm{z}}=\left(\frac{\varphi_{\mathrm{e}}}{\left(1-\varphi_{\mathrm{e}}\right)}\right)$

where $K=$ permeability, $\varphi_{\mathrm{e}}=$ effective porosity.

\section{Field geography}

West Qurna is one of the supergiant oilfields in southern Iraq, $70 \mathrm{~km}$ northwest of Basra city, and $14 \mathrm{~km}$ far off West Qurna city, the oilfield is neighboring to North Rumaila oilfield Fig. 3. 

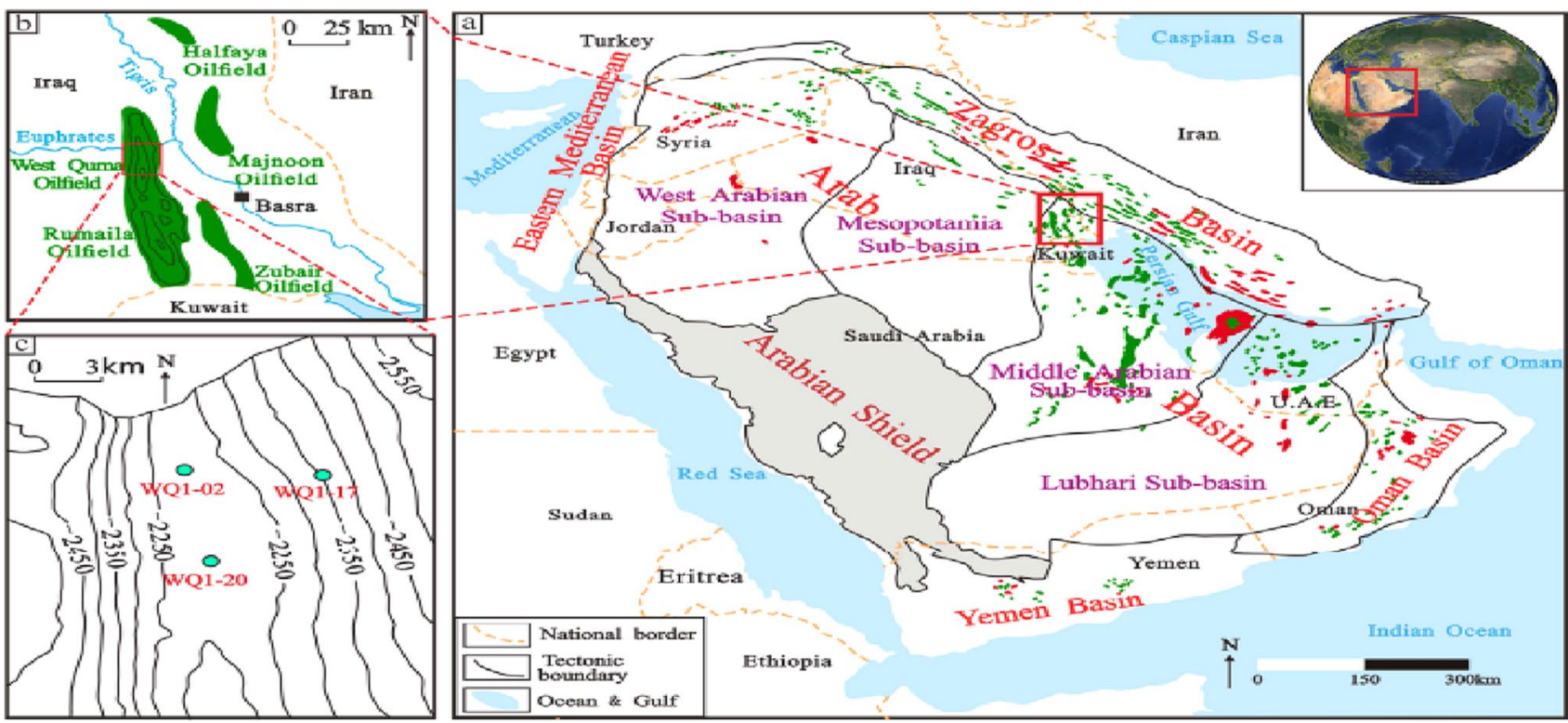

Fig. 3 West Qurna oilfield (Liu et al. 2018)

Structurally. This field is a section of the long axis-asymmetrical outspread isocline extended $10 \mathrm{~km}$ width and $40 \mathrm{~km}$ length. The isocline trends North-South, the trend changes at Northern field to NW-SE. The eastern flank's dip is about $1.6^{\circ}$, while the west flank's dip ranges $2^{\circ}-3.5^{\circ}$. The field is located on the outer platform of the Arabian Plate, in Mesopotamia's foredeep basin (Fouad 2010).

\section{Geological setting}

Mishrif Formation which represents the middle Cretaceous is the main carbonate reservoir in southern Iraqi fields, featured by heterogeneity and complication, this reservoir comprises six facies that graduated from mid-ramp facies to supratidal facies. Mishrif Formation in West Qurna oilfield is composed of three major reservoir units: $\mathrm{mA}, \mathrm{mB} 1$, and $\mathrm{mB} 2$ with two cap rocks units CRI and CRII. Mishrif Formation is a section of a second-Sort system trajectory of Arabian huge sequence 8 (AP8) (Sharland et al. 2001), this order begins from the Albian era to early Turonian. The Age of Mishrif is late Cenomanian to early Turonian from 95 to 89 MA (MA means mega-annum $=$ million years from the present) Fig. 4.

Mishrif Formation clarifies shallowing upward two periods in decline platform sort, this Formation shows six depositional environments Fig. 5. These environments are (Mahdi and Aqrawi 2014):

1. Mid-ramp environment facies that cover the open marine facies.

2. Rudist bioherm, these kinds of environments facies assorted as moderate to high energy with level and largescale fragment structure as rudist.

3. Shoal facies, Peloidal skeletal is packstone to grainstone rudists firmness, floatstone, and rudstone are describing the shoal environment facies.

4. Back-shoal facies, this environment combination known as skeletal peloids packstone, wackestone, and floatstone with few grainstone.

5. Lagoon facies, skeletal peloids wackestone, wackepackstone, and packstone structure characterized these environment progressions.

6. Tidal flat facies, this environment facies exhibited the shallowest water depositional region in this Formation.

Mishrif Formation is composed of rudist, algal, foraminifera, bivalves, coral, gastropods, and echinoderms. Facies are changing gradually from the mid-ramp to the lagoon facies and the formation is divided into five units: Cap Rock I, Upper Mishrif (mA), Cap Rock II, and Lower Mishrif. (mB1 and $\mathrm{mB} 2$, respectively. The heterogeneity 
Fig. 4 Stratigraphic column for southern Iraq (Mahdi and Aqrawi, 2014)

\begin{tabular}{|c|c|c|c|c|c|c|c|c|}
\hline \multicolumn{2}{|c|}{ Age } & \multirow{2}{*}{ 章 } & \multirow{2}{*}{ Formation } & \multirow{2}{*}{ Lith. } & \multirow{2}{*}{ Description } & \multirow{2}{*}{ 枲宸 } & \multirow{2}{*}{ AP } & \multirow{2}{*}{ 岂 } \\
\hline period & epoch & & & & & & & \\
\hline \multirow{7}{*}{ 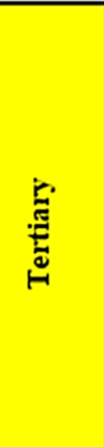 } & \multirow{2}{*}{$\begin{array}{c}\text { L. } \\
\text { Miocene - } \\
\text { Recent }\end{array}$} & \multirow{4}{*}{ 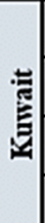 } & Q. deposits & & Clay and silt & 180 & \multirow{4}{*}{ AP11 } & \multirow{3}{*}{ IV } \\
\hline & & & Dubbdiba & 인 & Sand and gravel & 240 & & \\
\hline & \multirow{2}{*}{$\begin{array}{c}\text { E-M } \\
\text { Miocene }\end{array}$} & & Fatha & 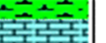 & Marl and limestone & 120 & & \\
\hline & & & Ghar & i & Sand and gravel & 90 & & III \\
\hline & $\begin{array}{c}\text { M-L } \\
\text { Eocene }\end{array}$ & \multirow{3}{*}{ 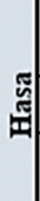 } & Dammam & & dolomite & 220 & \multirow{3}{*}{ AP10 } & \multirow{3}{*}{ I } \\
\hline & \multirow{2}{*}{ 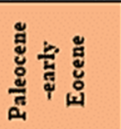 } & & Rus & & Anhydrite & 30 & & \\
\hline & & & $\begin{array}{c}\text { Umm- } \\
\text { Radhuma }\end{array}$ & & dolomite & 450 & & \\
\hline \multirow{15}{*}{ 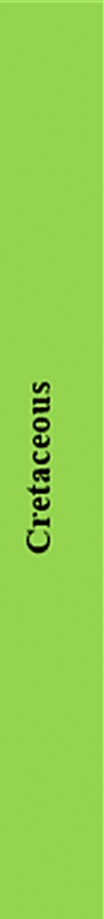 } & \multirow{6}{*}{ 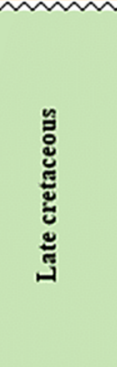 } & \multirow{6}{*}{ 족 } & Tayarat & Tी & dolomite & 260 & \multirow{6}{*}{ AP9 } & \multirow{3}{*}{ IV } \\
\hline & & & shiraish & 구도도돈 & Marly limestone & 105 & & \\
\hline & & & Hartha & 도돈 & Limestone and dolomite & 190 & & \\
\hline & & & Sadi & 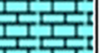 & Limestone & 220 & & \multirow{3}{*}{ IV } \\
\hline & & & Tanuma & & Shale & 45 & & \\
\hline & & & Khasib & 도도도도용 & Limestone & 60 & & \\
\hline & \multirow{5}{*}{ 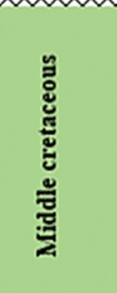 } & \multirow{5}{*}{ : } & Mishrif & 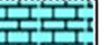 & Limestone & 180 & \multirow{10}{*}{ AP8 } & \multirow{3}{*}{ IV } \\
\hline & & & Rumaila & & Limestone & 80 & & \\
\hline & & & Ahmadi & 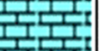 & Limestone & 140 & & \\
\hline & & & Mauddud & 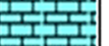 & Limestone & 110 & & \multirow{2}{*}{ III } \\
\hline & & & Nhr Umar & & Sand and Shale & 260 & & \\
\hline & & & Shuaiba & 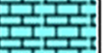 & Limestone and Dolomite & 80 & & \\
\hline & ๕ & 영 & Zubair & $\cdots$ & Sand and Shale & 400 & & \\
\hline & $\underline{0}$ & 司 & Ratawi & 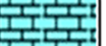 & Limestone with Shale & 260 & & \\
\hline & & 吾 & Yammama & 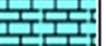 & Limestone & 280 & & I \\
\hline Jurassic & U-Jurassic & & suly & 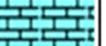 & Argillaceous Limestone & 240 & & \\
\hline
\end{tabular}

of the formation varies from homogeneity in the $\mathrm{mA}$ unit to higher anisotropy in the $\mathrm{mB} 1$ unit than $\mathrm{mB} 2$ unit (AlDujaili et al. 2021).

\section{Materials and methods}

\section{Materials}

The data used in this study have been extracted from 20 wells drilled in Mishrif formation in the West Qurna oilfield as in Figs. 6, 7, and Appendix 1. The number of plugs is shown in Table 3.

\section{Methods}

The coring task provided 4816 preserved cores, which were used in the first step for measuring the permeability and porosity of the samples. The core samples were extracted from Mishrif Formation, and the average rock density of the core was measured to be $2.691 \mathrm{~g} / \mathrm{cm} 3$. The laboratory measurements (RCA) were conducted. 


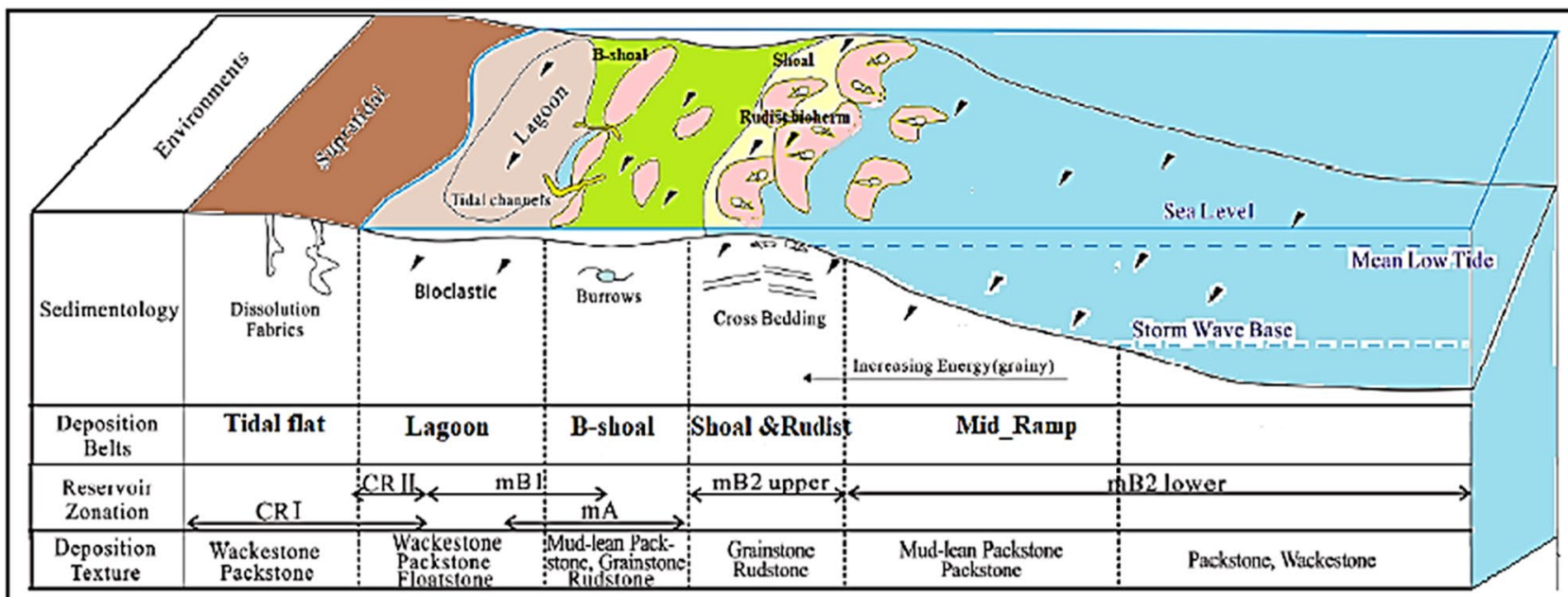

Fig. 5 Depositional environments for Mishrif Formation in the West Qurna oilfield (Sharland et al., 2001)

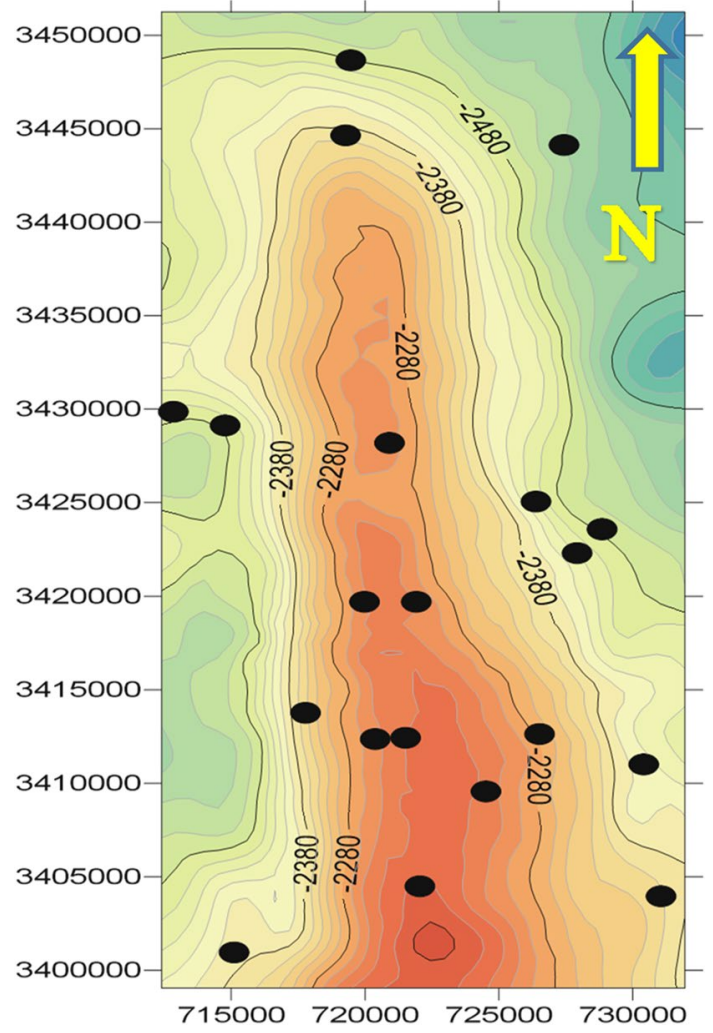

Fig. 6 Well locations in Mishrif contour map

The second step in this study was to insulate the plugs stated according to the layers depending on the upper and lower limit of each unit and also on the specified depth that each core has been taken from a certain well. The data have been analyzed and tabulated for each unit of Mishrif Formation Figs. 8 and 9.

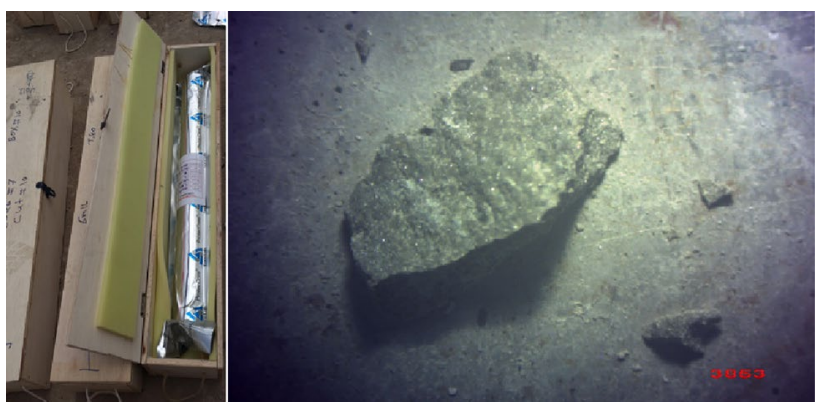

Fig. 7 Core handling and a core sample from a well in West Qurna oilfield

Table 3 Plugs numbers used in the study

\begin{tabular}{llll}
\hline Mishrif unit & No. of Plugs & Range of $\varphi(\mathrm{v} / \mathrm{v})$ & Range of $K(\mathrm{mD})$ \\
\hline $\mathrm{mA}$ & 1024 & $0.010-0.319$ & $0.01-1384$ \\
$\mathrm{CRII}$ & 80 & $0.021-0.267$ & $0.001-282$ \\
$\mathrm{mB} 1$ & 1284 & $0.010-0.352$ & $0.01-2214$ \\
$\mathrm{mB} 2$ & 1528 & $0.019-0.377$ & $0.01-1350$ \\
\hline
\end{tabular}

\section{Results}

Core data values for porosity and permeability of 20 wells for Mishrif reservoir in West Qurna oil field were used to determine rocks type, pore throat radius, and flow units for Upper Mishrif (mA), Cap Rock II, and Lower Mishrif. (mB1 and $\mathrm{mB} 2$ units, respectively. Techlog software 2015.3 has been used to determine rocks type, pore throat radius, and 

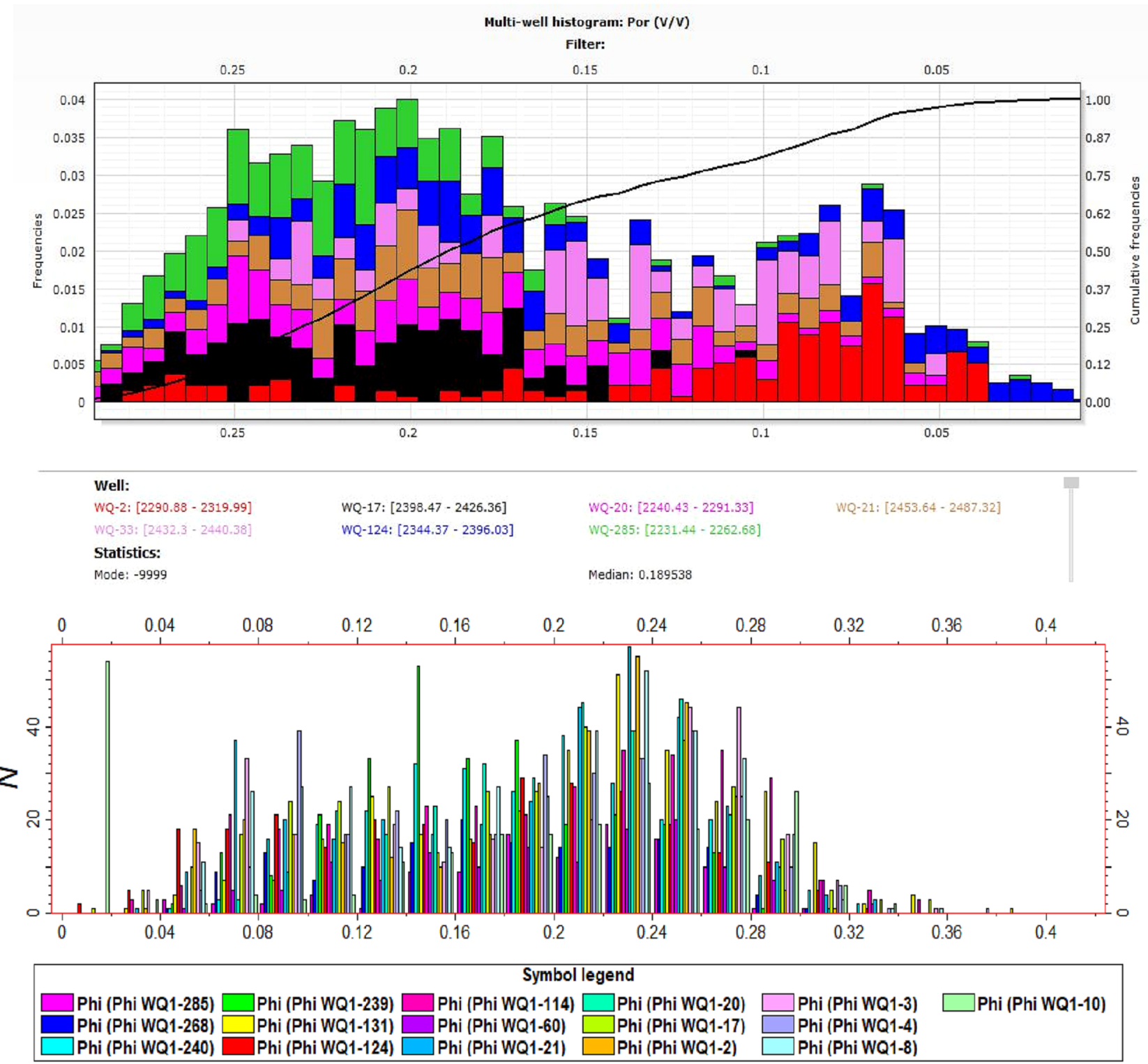

Fig. 8 Porosity histogram according for wells lithofacies by Techlog software

flow units. The results are presented and discussed for all units in the following:

\section{Rocks type}

By using rocks type classification (Lucia 2007), the results for all units are shown in Fig. 9. mA unit shows rocks type in class 1 lower than in $\mathrm{mB} 1$, which reflects the rare grainstone. The small grain size makes most of the rocks forming this unit are classes 2 and 3 (pack-wackestone, wackestone, mudstone, and with packstone but in low percentage) (Fig. 10).
For the cap rock II unit, it has been seen that the variation in rock type is very noticeable in the unit which covers all classes.

Rocks type of $\mathrm{mB} 1$ unit enhances rock properties as compared with unit mB2. Rocks type of facies continues to be consists of classes 2 and 3 while in some wells the grainstone increased noticeably.

For the mB2 unit, class 2 wackestone and packstone were the main rocks of this reservoir unit when correlated with core description and microfacies thin section and the result was the same microfacies. The $\mathrm{mB} 2$ environment graded from mid-ram environments at the lower section to 


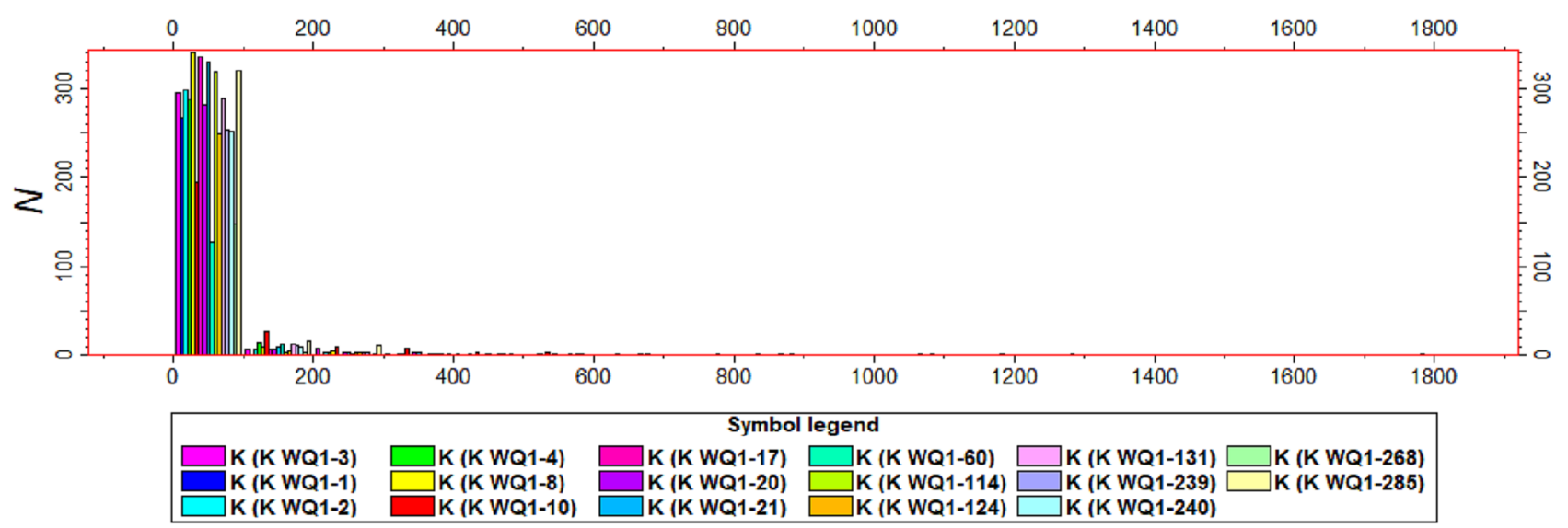

Fig. 9 Permeability histogram according for wells lithofacies by Techlog software 2015.3
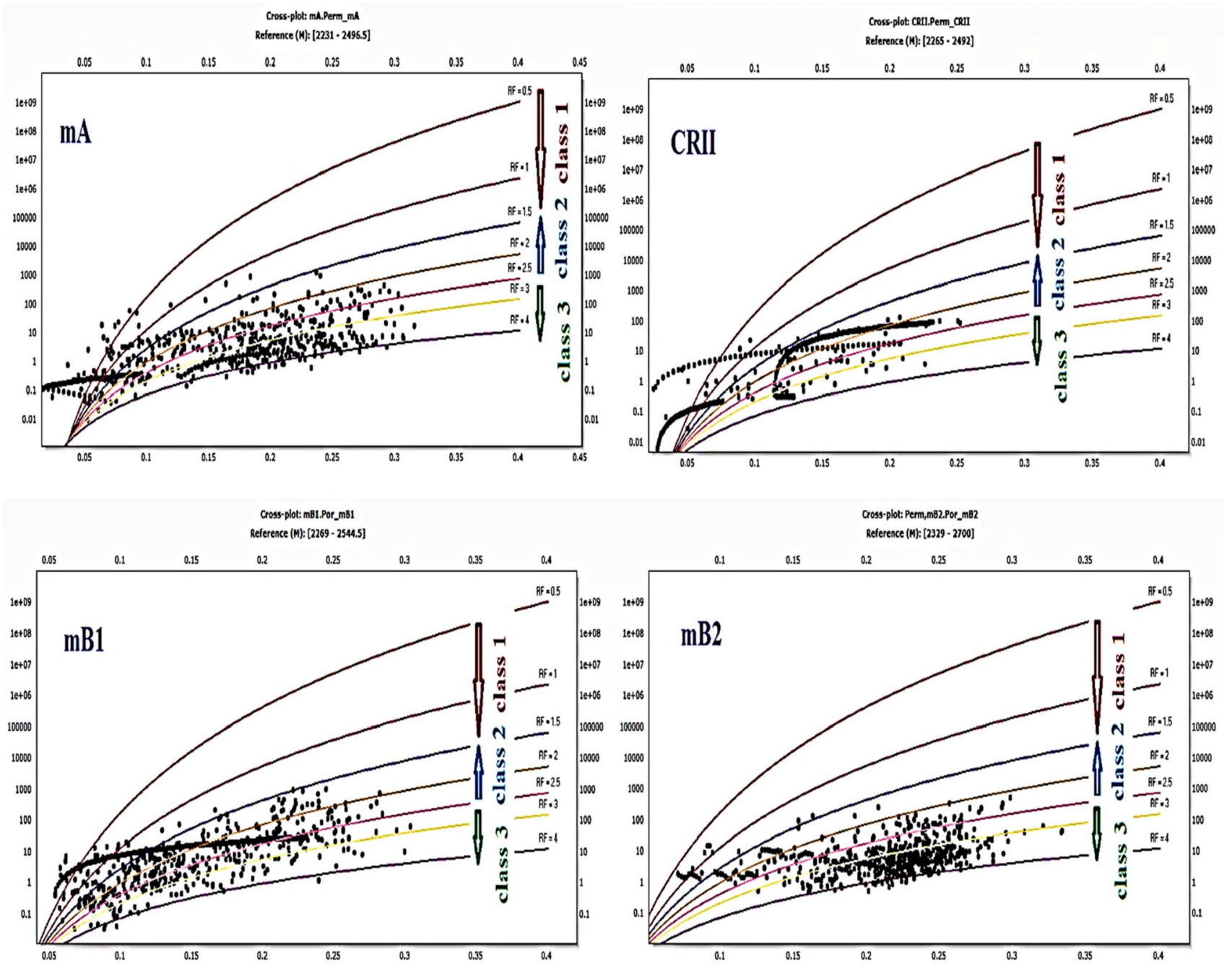

Fig. 10 Rocks Type for all units of Mishrif units 

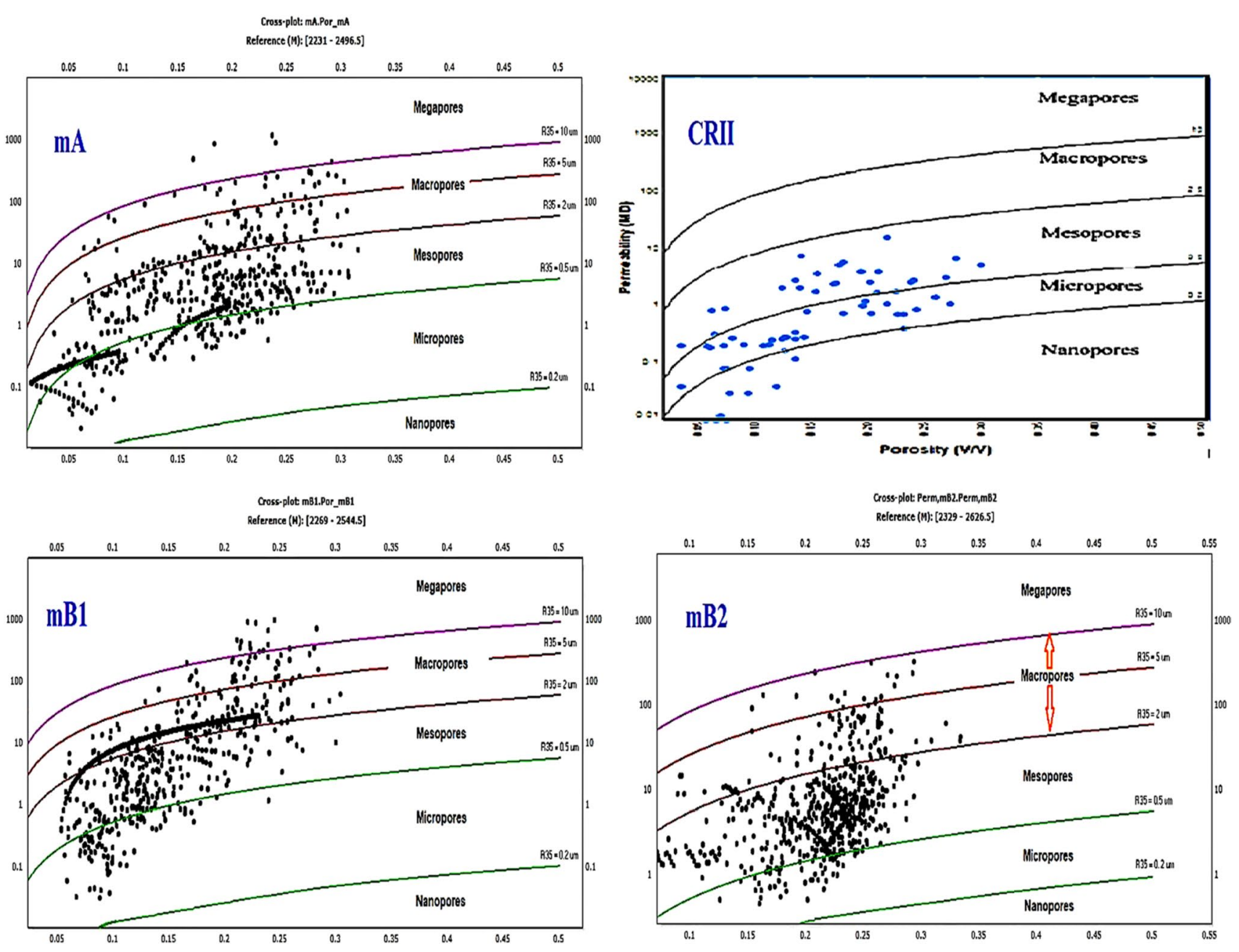

Fig. 11 Pore Throat Radius for all units of Mishrif

shoal and rudest bioherm at the upper section of the unit. Class 1 grainstone has been noticeable rarely in this unit.

\section{Pore throat radius}

Pore throat radius of unit $\mathrm{mA}$ were macropores and mesopores correlated wackestone, packstone, and low percentage of grainstone microfacies in the northern part of the formation. While the pore throat radius was mesopores with a rare percentage as macropores and microspores in the southern part of the unit (Fig. 11).

According to Fig. 11, the CRII unit is composed generally of nanopores and micropores in the south of the formation and it will transfer to mesopores in the northern part of the unit.

For the mB1 unit, it enhanced as rocks type, megapores noticed as the major distribution in this unit with some macropores. Macropores correlated the grainstone when correlated with microfacies. Rudist, benthic foraminifera, coral, and echinoderms microfacies. On the other hand, mesopores equivalent packstone when the bioclast grains decrease in microfacies.

The $\mathrm{mB} 2$ unit was better in the north of the formation also where pores throat radius type was mesoporous and some points were microspores, while southern part points distributed between microporous and mesopores as shown in (Fig. 11).

\section{Flow units}

\section{The upper Mishrif (mA)}

In this part, three flow units are observed as in Figs. 12, 13 with moderate regression of about 0.7 . 

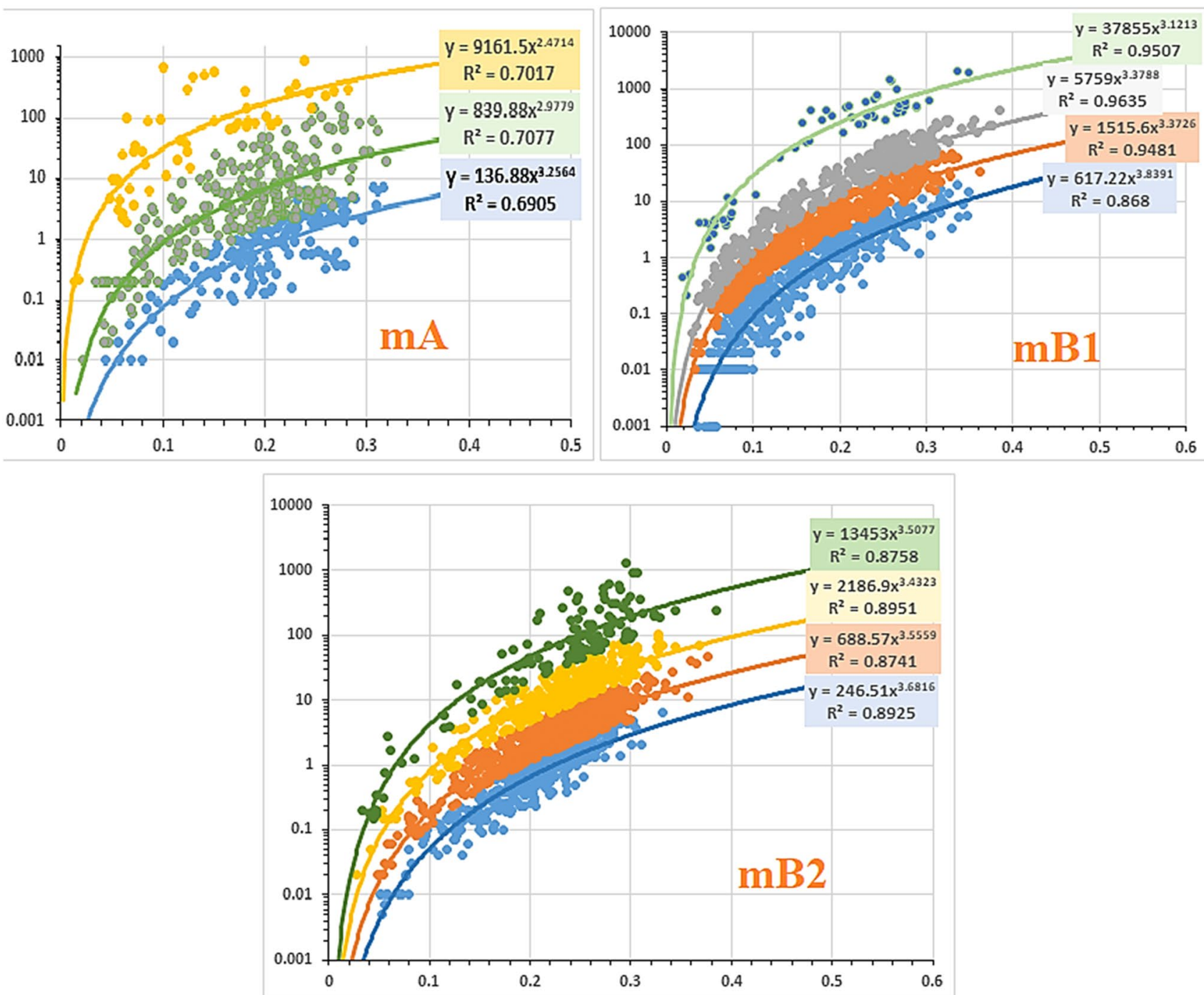

Fig. 12 Flow units for the upper Mishrif (mA) and the lower Mishrif (mB1, mB2)

\section{The lower Mishrif (mB1, mB2)}

The lower Mishrif which consists of $\mathrm{mB} 1, \mathrm{mB} 2$ units has eight flow units as in Figs. 12, 13 with a good regression of about 0.9 .

\section{Discussion}

Many previous studies dealt with rocks type, pore throat radius, and flow units but the determination of these characterizations was done either from electrofacies or limited lithofacies data. This study tried to be more accurate by using lithofacies data from many locations in the field. By using bigger project area with bigger number of the wells could provide broader picture of the reservoir description.
According to the rocks type and pore throat radius results, the study diagnosed the following:

\section{High porosity, high permeability rock}

Reservoir flow units correspond to skeletal-dominated grainstone/ rudstone facies (class1). Dominant pore types include inter-particle and moldic porosity types. Pore throat sizes average around 4-15 microns. High flow zones within the mB1 lagoonal system. High flow zones (grainstone) within the upper part of the $\mathrm{mA}$ unit are best developed in the upper $\mathrm{mA}$ higher permeability flow units and finally, the high flow zone in the upper mB2 shoal facies with pore throat sizes average around $4-10$ microns. 


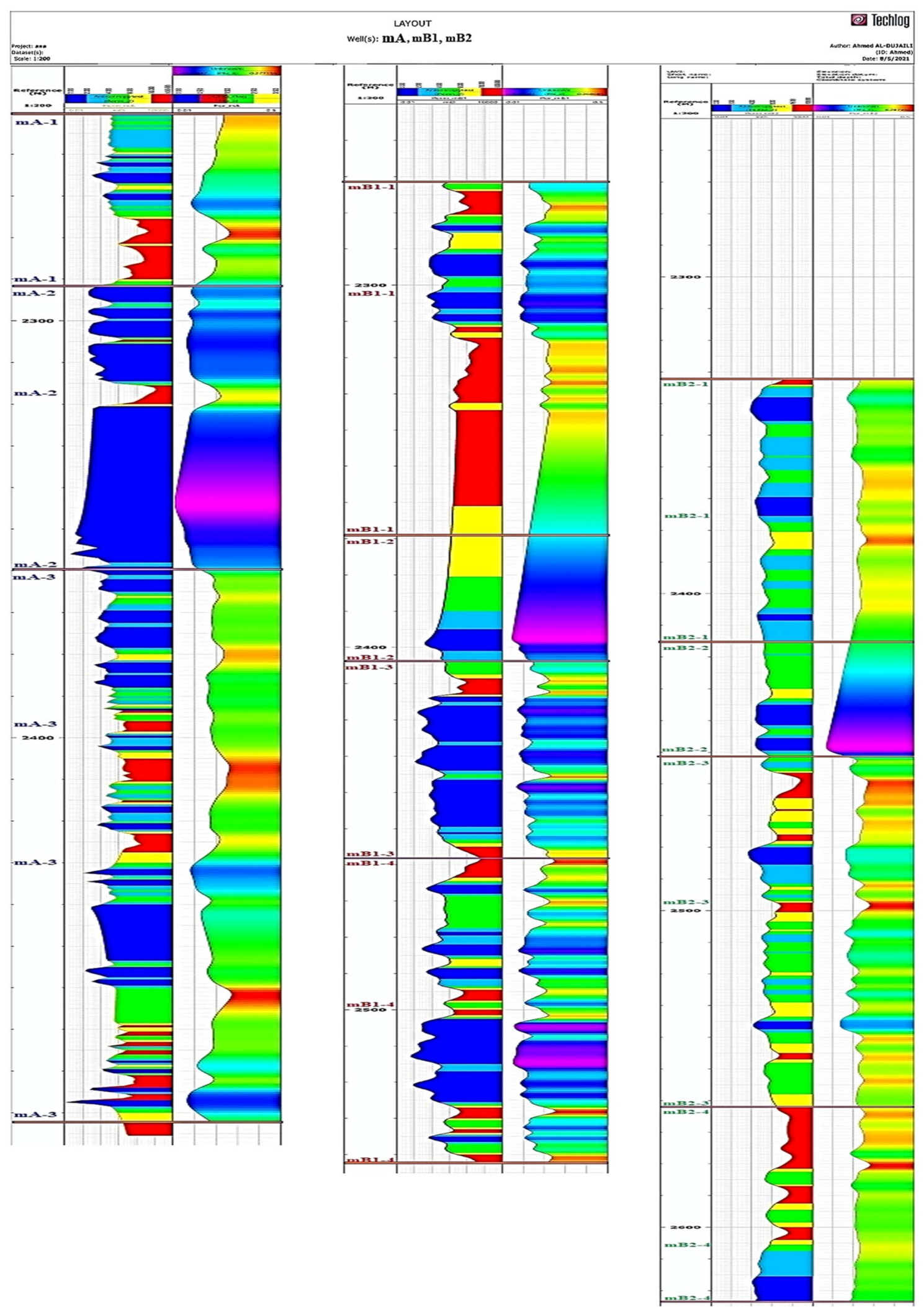

Fig. 13 Flow units for the upper Mishrif (mA) and the lower Mishrif (mB1, mB2) by Techlog software 2015.3 


\section{High porosity, low permeability rock (high storage, low flow potential)}

Rocks types 2 and 3 correspond to facies with packstone/ wackestone textures and are dominated by microporosity Pore throat sizes average around $2-0.5$ microns. This rocks type includes the lower part of $\mathrm{mB} 2$ which is marked as midramp facies and the lower part of the $\mathrm{mA}$ unit.

\section{Low porosity, low permeability rock (barriers and baffles)}

This reservoir rock type is characterized by low porosity chalky limestone and class 3 rocks type, low permeability rocks are developed around sequence boundaries and in restricted lagoonal facies in the upper part of the $\mathrm{mB} 1$ zone and the lower part of $\mathrm{mA}$. Pore throat sizes average less than 0.2 microns. Low reservoir quality in these rock types is due to cementation correlated with exposure surfaces.

The results of flow units for the upper Mishrif (mA) and the lower Mishrif (mB1, mB2) by (FZI) method showed that among those reservoir units, $\mathrm{mB} 1.4$ is considered as one of the most important reservoir unit in Mishrif reservoir in West Qurna oil field.

Units' mA.2, mB1.3, mB2.2, and mB2.4 may be classified as very good to good reservoir.

Units' mA.1 and mB1.1 are of moderate reservoir characteristics, while units' $\mathrm{mB} 1.1, \mathrm{~mA} .3$, and $\mathrm{mB} 2.3$ have comparatively poorer reservoir characteristics and may be classified as bad reservoir.

The cap rock is placed at the bottom of the mA.3 reservoir units. This unit has very low porosity and permeability values. The pore type is nanopores and micropores with some mesopores.

\section{Conclusion}

This study involved the relationship between petrophysical properties (porosity and permeability), using core data then correlate the result to determine rocks type, pore throat radius, and flow units as follows:

1. The rocks types of unit $\mathrm{mB} 2$ were mostly ranged from wackestone to packstone which reflected mid-ramp facies while the upper part of $\mathrm{mB} 2$ referred to shoal facies.

2. The rocks type of $\mathrm{mB} 1$ unit where mostly range from packstone to grainstone with some points as wackestone marked as shoal and rudist bioherm facies.

3. Unit $\mathrm{mA}$ has a variety of rocks types due to facies ranged from rudist bioherm or shoal facies to supratidal facies in the upper part of the $\mathrm{mA}$ unit.

4. Megaporous and macroporous referred to rudstone and grainstone when correlated with core data with a high energy environment as shoal or rudist bioherm facies. Mesoporous throwback the medium energy level and packstone microfacies are dominated by microfacies back-shoal facies. Microporous mostly wackestone symbolize lagoon and mid-ramp facies.

5. Pore throat radius of unit $\mathrm{mA}$ were macropores and mesopores in the northern part of the formation, while the pore throat radius was mesopores with a rare percentage as macropores and microspores in the southern part of the unit.

6. For the mB1 unit, Megapores are the major distribution with some macropores. Macropores.

7. The mB2 unit was better in the north of formation also where pores throat radius type is mesoporous and some points were microspores, while southern part points distributed between microporous and mesopores.

8. The upper Mishrif ( $\mathrm{mA}$ ) has three flow units while the lower Mishrif which consists of $\mathrm{mB} 1, \mathrm{mB} 2$ units has eight flow units. 
Funding The authors declare that they have no known competing financial interest.

\section{Declarations}

Conflict of interest The authors declare that they have no known competing financial interests or personal relationships that could have appeared to influence the work reported in this paper.

Ethics approval We believe the findings in this paper will be of interest to the readers of journal. We declare that this manuscript is original, has not been published before and is not currently being considered for publication elsewhere.

Consent to participate We know of no conflict of interest associated with this publication and I as corresponding author confirm that the manuscript has been read and approved for submission by all the named authors for all readers (open access).

Consent for publication Ahmed Noori Al-Dujaili, Mehdi Shabani, and Mohammed Salih AL-Jawad to be considered for publication as an original paper in the Journal of Petroleum Exploration and Production Technology.

Open Access This article is licensed under a Creative Commons Attribution 4.0 International License, which permits use, sharing, adaptation, distribution and reproduction in any medium or format, as long as you give appropriate credit to the original author(s) and the source, provide a link to the Creative Commons licence, and indicate if changes were made. The images or other third party material in this article are included in the article's Creative Commons licence, unless indicated otherwise in a credit line to the material. If material is not included in the article's Creative Commons licence and your intended use is not permitted by statutory regulation or exceeds the permitted use, you will need to obtain permission directly from the copyright holder. To view a copy of this licence, visit http://creativecommons.org/licenses/by/4.0/.

\section{References}

Abbas Mohammed A, Al Lawe EM (2019) Clustering analysis and flow zone indicator for electrofacies characterization in the upper shale member in luhais oil field, southern Iraq. In: Abu Dhabi international petroleum exhibition \& conference, Abu Dhabi, UAE. doi:https://doi.org/10.2118/197906-MS

Abbaszadeh M, Fujii H, Fujimoto F (1996) Permeability prediction by hydraulic flow units-theory and applications. SPE. https://doi. org/10.2118/30158-PA

Ahr WM (2008) Geology of carbonate reservoirs: the identification, description, and characterization of hydrocarbon reservoirs in carbonate rocks. Wiley, Hoboken

Al-Dujaili AN, Shabani M, M.S. AL-Jawad, (2021) Identification of the best correlations of permeability anisotropy for Mishrif reservoir in West Qurna/1 oil Field, Southern Iraq. Egypt J Pet. https:// doi.org/10.1016/j.ejpe.2021.06.001

Al-Ibadi H, Al-Jawad S (2020) Determination of flow units by integrating petrophysical properties of a giant middle east carbonate reservoir. doi:https://doi.org/10.3997/2214-4609.202011926

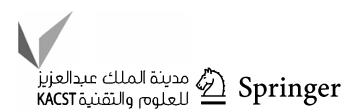


Al-Mudhafar WJ, Al Lawe EM, Noshi CI (2019) Clustering analysis for improved characterization of carbonate reservoirs in a southern Iraqi oil field. In: Offshore technology conference. Houston, Texas. doi:https://doi.org/10.4043/29269-MS

Amaefule JO, Al-tunbay MH, Tiab D, Kersey DG, Keelan DK (1993) Enhanced reservoir description using core and log data to identify hydraulic (flow) units and predict permeability in uncored intervals/wells. doi:https://doi.org/10.2118/26436-MS

Awadeesian MR, Al-Jawed SN, Afrah HS, Govand HS (2015) Mishrif carbonates facies and diagenesis glossary, south Iraq microfacies investigation technique: types, classification, and related diagenetic impacts. Arab J Geosci. https://doi.org/10.1007/ s12517-015-1954-9

Choquette PW, Pray LC (1970) Geologic nomenclature and classification of porosity in sedimentary carbonates. https://archives.datap ages.com/data/bulletns/1968-70/data/pg/0054/0002/0200/0207. $\mathrm{htm}$ ?q=\%2BtitleStrip\%3Ageologic+titleStrip\%3Anomenclature+ titleStrip\%3Aclassification+titleStrip\%3Aporosity+titleStrip\% 3Asedimentary+titleStrip\%3Acarbonates

Deng Y, Guo R, Zhongyuan TW, Yi Y, Xu Z, Xiao C, Cao X, Chen L (2016) Geologic features and genesis of the barriers and intercalations in carbonates: a case study of the Cretaceous Mishrif Formation, West Qurna oil field, Iraq. PetroleumExplorationandDevelopment. doi:https://doi.org/10.1016/S1876-3804(16)30018-0

Ebanks WJ Jr, Scheihing MH, Atkinson CD (1992) Flow units for reservoir characterization. AAPG. http://www.sepmstrata.org/CMS Files/book_reviews\%20-\%20aapg-meth-expl-10.pdf

Fouad SF (2010) Tectonic and structural evaluation of the Mesopotamia foredeep, Iraq. Iraqi bulletin of geology and mining. https:// www.iasj.net/iasj/download/90ea30a2b47199ca

Gunter GW, Finneran JM, Hartmann DJ, Miller JD (1997) Early determination of reservoir flow units using an integrated petrophysical method. In: SPE-38679. doi:https://doi.org/10.2118/38679-MS

Haikel S, Rosid MS, Haidar MW (2018) Study comparative rock typing methods to classify rock type carbonate reservoir Field "S" East Java. In: Publishing IOP (ed) Journal of physics: conference series, vol 1120. Bristol, pp 1120-012047. https://doi.org/10. 1088/1742-6596/1120/1/012047

Hearn CL, Ebanks W, Tye RS, Ranganathan V (1984) Geological factors influencing reservoir performance of the hartzog draw field wyoming. J Pet Technol 36(08):1335-1344. https://doi.org/10. 2118/12016-PA

Hussain SA, Al-Obaidi M, Ahmad K (2020) Facies architecture, diagenesis and paleoceanography of mishrif (late cretaceous) in selected wells of west Qurna oil field, southern Iraq. doi:https:// doi.org/10.1088/1742-6596/1664/1/012137

Ismail MJ, Al-Najm FM (2019) Utilizing core and nmr data to identify rock-type and pore throat radius for mishrif formation in west Qurna oilfield. http://igj-iraq.org/igj/index.php/igj/article/view/155

Liu H (2018) Principles and applications of well logging. Springer, New York. https://doi.org/10.1007/978-3-662-54977-3

Lucia FJ (2007) Carbonate reservoir characterization. Springer, Berlin, Heidelberg. https://doi.org/10.1007/978-3-540-72742-2

Mahdi TA, Aqrawi AM (2014) Sequence stratigraphic analysis of the mid-cretaceous Mishrif formation, southern Mesopotamian basin, Iraq. J Pet Geol. https://doi.org/10.1111/jpg.12584

McCreery E, Al-Mudhafar W (2017) Geostatistical classification of lithology using partitioning algorithms on well log data - a case study in forest hill oil field, East Texas Basin. In: 79th EAGE conference and exhibition, At Paris, France. doi:https://doi.org/ 10.3997/2214-4609.201700905

Porras JC, Campos O (2001) Rock typing: a key approach for petrophysical characterization and definition of flow units, santa barbara field, eastern Venezuela Basin. In: SPE latin american and caribbean petroleum engineering conference. Society of Petroleum Engineers. doi:https://doi.org/10.2118/69458-MS

Sharland PR, Archer R, Casey DM (2001) Arabian plate sequence stratigraphy. Geo Arabia Special Publication, Gulf Petro link, Bahrain

Tang H, White C, Zeng X, Gani M, Bhattacharya J (2004) Comparison of multivariate statistical algorithms for wireline log facies classification. AAPG Ann Meet Abstr 88:13

Winland HD (1976) Evaluation of gas slippage and pore aperture size in carbonate and sandstone reservoirs: Amoco Production Company Report

Publisher's Note Springer Nature remains neutral with regard to jurisdictional claims in published maps and institutional affiliations. 